\title{
The Impact of Poverty in the Young Ecuadorian Citizens Aged 5-14: A Data Analysis
}

\author{
Fernando Pesántez Avilés ${ }^{1}$, Vladimir Robles Bykbaev ${ }^{1} \&$ Efstathios Stefos ${ }^{2}$ \\ ${ }^{1}$ UNESCO Chair on Support Technologies for Educational Inclusion, Universidad Politécnica Salesiana, Azogues, \\ Ecuador \\ ${ }^{2}$ Universidad Nacional de Educación UNAE, Azogues, Ecuador \\ Correspondence: Efstathios Stefos, Universidad Nacional de Educación UNAE, Azogues, Cañar, Parroquia Javier \\ Loyola (sector Chuquipata), Ecuador. Tel: 593-7-370-1200. E-mail: estefos@aegean.gr
}

Received: May 11, 2017

Accepted: May 24, 2017

Online Published: June 20, 2017

doi:10.5539/res.v9n3p53

URL: http://doi.org/10.5539/res.v9n3p53

\begin{abstract}
The objective of the study is to examine the educational and social profile of young people aged 5-14 of Ecuador by means of a statistical analysis of this sector of the Ecuadorian population, based on data from the National Survey of Employment, Unemployment and Underemployment from 2015. The statistical analysis shows the frequency and percentages of the variables used in the investigation. We use contingency tables in order to explore the relationship between the variables under investigation and the poverty in this age group.
\end{abstract}

Keywords: Ecuador, young people aged 5-14, social profile, data analysis

\section{Introduction}

The inclusive social policies, especially the ones focused on supporting childhood, at any stage of risk of vulnerability, require that the perceptions of those self-called the poor be complemented with objectively rated characteristics since this is the proof to confirm their condition of poverty. This article presents correlations between two contrary groups, poor-non-poor, which from determiners such as access to education, possession of goods and basic services allow to identify, in a critical population such as the Ecuadorian children ranging from 5 to 14 years old, some regular factors that define each segment (Castellano et al., 2017).

In Ecuador, the National Institute of Statistics and Census (INEC) is in charge of the production of statistical information in the country through the National Survey of Employment, Unemployment and Underemployment (ENEMDU), which is a basic tool in planning, evaluation, monitoring and design of social policies providing statistical information (Stefos \& Koulianidi, 2016).

The data at the country level, between 2006 and 2015, show the decrease of poverty according to the income in the last 10 years (age 5-14 years old); thus, the segment considered "poor" decreased from $48.09 \%$ to $32.76 \%$ (INEC, 2006-2015); supported by a growth of $14.86 \%$ of the segment considered "non-poor". However, comparing the population data, at the same time, is perceptible that the $14.86 \%$ which represents 661301 persons, aged 5-14, result not only in numerical reduction of the first segment " 359983 poor persons" but also in the complementation with values of the population growth of the last 10 years, for the ages of 5-14, which reached 318246.

Except for the higher education, which is governed by its own norm, the Organic Law of Intercultural Education (LOEI, 2011), orients the Ecuadorian education within the framework of Good Living (Buen Vivir) and the interculturality. Regarding the formal schooling, this one is complete in three levels of education; preschool, elementary and secondary. Considering that:

"The basic general education develops the skills, abilities, and competencies of the children and teenagers from 5 years old on to participate critically, responsibly and mutually in the citizen life and continue the secondary studies. The basic general education is composed of ten years of compulsory attention" (LOEI, 2011).

In the same way, there is, in Ecuador, an improvement of the net rate of enrolment in the school system of the 4-15-year-old children which in the last decade went from $93.02 \%$ to $97.54 \%$, which means the inclusion in the educational system of around 3265205 persons. It can be said there is an evident expansion of the educational coverage at this level in which the social and personal development is strengthened, extended and deepened. The 
discovery of the natural and cultural environment, and the expression and communication, as axes of development and learnings. Besides, at this level basic disciplines that contribute to the cultural and linguistic diversity are included (Papapostolou \& Stefos, 2013).

From the data of the OECD of 2015 (Education at a Glance, 2015), if we compare the net rates of enrolment in the population under study, regarding developed countries that lead the processes of coverage and quality in education, it can be pointed that in terms of coverage, the general basic education in Ecuador fulfils its principle of university. The net rate of enrolment in Ecuador (97.54\%) overcomes its analogues from Finland (96.78\%), Spain (97.45\%) and USA (96.86\%); at the level of region, it has more representation that Chile which reached $97.33 \%$ in 2015 (Valdivieso et al., 2017).

The segment considered "poor", aged 4-15 years old, is distributed in the relatively near percentages both in the urban zones and in the rural since the percentage breach does not reach 10 points. However, it is not the case in the segment considered "non-poor" which has more presence in the urban zones $(72.25 \%)$ and overcomes the rural zone for almost over 45 percentage points. Considering the loving costs for coverage of basic services, plus the food and housing costs result less high in the rural sector. It seemed logical the correspondence happening at such sector where most of the considered poor population, which reached 602700 people at the mentioned ages in 2015, is located (Williams Goodrich et al., 2017).

However, what was mentioned before regarding costs, the conformation of the urban population, for the ones aged 4-15 years old, states that for each poor persons at such place there are, at least, 3.24 non-poor while in the rural population the relation is practically one to one; hence, the costs issue is not a considerable variable to correlate (Sarmiento et al., 2016).

\section{Method}

The study uses as reference statistical information from the 2015 National Survey of Employment, Unemployment and Underemployment (INEC, 2015). Given the objective of the present study, a descriptive analysis was performed, with the former showing the frequency and percentages of the variables under investigation (Kampouropoulou et al., 2015). The statistical analysis shows the frequency and percentages of the variables used in the investigation. We used contingency tables in order to explore the relationship between the variables under investigation and the poverty in this age group (5-14). The statistical software $\mathrm{R}$ was used to analyse the data (Stefos \& Papapostolou, 2013).

\section{The Data Analysis}

If the gender is considered, the relations determine that the proportion among poor men in relation to the non-poor is of 2.05, and in the case of women, it is of 1.99; consequently, for each poor man or woman, there are at least two considered non-poor (Table 1).

Table 1. Gender

\begin{tabular}{ccccc}
\hline & \multicolumn{2}{c}{ Poor } & \multicolumn{2}{c}{ Non-poor } \\
\cline { 2 - 5 } & $\mathrm{n}$ & $\%$ & $\mathrm{n}$ & $\%$ \\
\hline Men & 549402 & $50.09 \%$ & 1129943 & $50.90 \%$ \\
Women & 547358 & $49.91 \%$ & 1089958 & $49.10 \%$ \\
Total & 1096760 & $100.00 \%$ & 2219901 & $100.00 \%$ \\
\hline
\end{tabular}

Regarding the non-attendance to the educational institutions by the "poor" and "non-poor", there are substantial differences with regard to number of people; however, relating to the total of each segment, it is noticeable that 3.71 out of 100 poor students do not arrive at their schools while with the non-poor the relation is of 1.90 (Table 2).

Table 2. Attend classes

\begin{tabular}{ccccc}
\hline & \multicolumn{2}{c}{ Poor } & \multicolumn{2}{c}{ Non-poor } \\
\cline { 2 - 5 } & $\mathrm{n}$ & $\%$ & $\mathrm{n}$ & $\%$ \\
\hline Yes & 1056030 & $96.29 \%$ & 2177676 & $98.10 \%$ \\
No & 40730 & $3.71 \%$ & 42226 & $1.90 \%$ \\
Total & 1096760 & $100.00 \%$ & 2219901 & $100.00 \%$ \\
\hline
\end{tabular}


It can be summarized up to this point that there is a decrease of poverty by income in the last decade. Likewise, there is an expansion of the educational coverage which is at the level of countries considered as references. Also, the distribution of poverty is not necessarily correlated to the living costs according to de place of residency, and there is a proportion of almost twice of non-poor men and women compared to those who are poor. In proportion, the poor are the ones who attend less an educational centre than the non-poor. The working time preferred by both poor and non-poor is the daily hours, followed by the morning hours; only in the case of the noon-poor in small proportions the nightly and full-day is an option (Table 3 ).

Table 3. Working time they attend

\begin{tabular}{ccccc}
\hline & \multicolumn{2}{c}{ Poor } & \multicolumn{2}{c}{ Non-poor } \\
\cline { 2 - 5 } & $\mathrm{n}$ & $\%$ & $\mathrm{n}$ & $\%$ \\
\hline Morning & 897713 & $81.85 \%$ & 1830316 & $82.45 \%$ \\
Afternoon & 153720 & $14.02 \%$ & 335576 & $15.12 \%$ \\
Night & 0 & $0.00 \%$ & 2613 & $0.12 \%$ \\
Full-day & 0 & $0.00 \%$ & 352 & $0.02 \%$ \\
Two working sessions & 3794 & $0.35 \%$ & 7992 & $0.36 \%$ \\
Distance & 803 & $0.07 \%$ & 826 & $0.04 \%$ \\
NA & 40730 & $3.71 \%$ & 42226 & $1.90 \%$ \\
Total & 1096760 & $100.00 \%$ & 2219901 & $100.00 \%$ \\
\hline
\end{tabular}

Most of the population speaks the official language of the country, Spanish. However, $12 \%$ of the poor population complements Spanish with their indigenous language; at least 58076 non-poor persons do it. Regarding a complement with a foreign language, 17049 non-poor people do it linked to either Spanish or the indigenous language compared to 689 poor with same references. It is interesting that 1775 poor people speak only one foreign language and be more than the poor who combine Spanish or their indigenous language with a foreign language (Table 4).

Table 4. Language spoken (age: 5-14, 2015)

\begin{tabular}{lcccc}
\hline & \multicolumn{2}{c}{ Poor } & \multicolumn{2}{c}{ Non-poor } \\
\cline { 2 - 5 } & $\mathrm{n}$ & $\%$ & $\mathrm{n}$ & $\%$ \\
\hline Indigenous Language Only & 3903 & $0.36 \%$ & 2207 & $0.10 \%$ \\
Indigenous Language and Spanish & 137809 & $12.57 \%$ & 58076 & $2.62 \%$ \\
Spanish Only & 951821 & $86.78 \%$ & 2137892 & $96.31 \%$ \\
Spanish and Foreign Language & 577 & $0.05 \%$ & 16932 & $0.76 \%$ \\
Indigenous and Foreign Language & 112 & $0.01 \%$ & 117 & $0.01 \%$ \\
Foreign Language & 1775 & $0.16 \%$ & 2525 & $0.11 \%$ \\
Do not speak & 764 & $0.07 \%$ & 2151 & $0.10 \%$ \\
Total & 1096760 & $100.00 \%$ & 2219901 & $100.00 \%$ \\
\hline
\end{tabular}

Concerning the racial self-identification, among the poor and non-poor prevails to be considered mestizo followed, in percentages, by the Indigenous, Montubio, and Black. These last three added up to Mulatto and Afro-Ecuadorian are not only linked to populations considered poor. To state in numbers, there are more persons considered black and non-poor that the ones considered black and poor as well as in the case of Montubios, Mulatto and Afro-Ecuadorians. Only in the case of indigenous, the relation is reversed. Likewise, regarding those self-identified as white are not only linked to the non-poor (Table 5). 
Table 5. How they identify themselves

\begin{tabular}{lcccc}
\hline & \multicolumn{2}{c}{ Poor } & \multicolumn{2}{c}{ Non-poor } \\
\cline { 2 - 5 } & $\mathrm{n}$ & $\%$ & $\mathrm{n}$ & $\%$ \\
\hline Indigenous & 209550 & $19.11 \%$ & 130930 & $5.90 \%$ \\
Afro-Ecuadorian & 17372 & $1.58 \%$ & 26735 & $1.20 \%$ \\
Black & 31985 & $2.92 \%$ & 36580 & $1.65 \%$ \\
Mulatto & 19248 & $1.75 \%$ & 25798 & $1.16 \%$ \\
Montubio & 73500 & $6.70 \%$ & 85608 & $3.86 \%$ \\
Mestizo & 731204 & $66.67 \%$ & 1881369 & $84.75 \%$ \\
White & 13671 & $1.25 \%$ & 32639 & $1.47 \%$ \\
Other & 231 & $0.02 \%$ & 241 & $0.01 \%$ \\
Total & 1096760 & $100.00 \%$ & 2219901 & $100.00 \%$ \\
\hline
\end{tabular}

With respect to the work field, it can be seen that the percentage of poor children who worked the last week was bigger than the percentage of non-poor children that work. However, the reading should be done considering that the total of the poor is of 1096760 and $4.67 \%$ worked, which is equivalent to 51240 children, and in the case of the non-poor, the values are 2219901 and $1.81 \%$ which represents 40108 . From there, we can see that a major amount of poor worked the last week compared to the amount of the non-poor who worked as well (Table 6).

Table 6. Worked the last week

\begin{tabular}{ccccc}
\hline & \multicolumn{2}{c}{ Poor } & \multicolumn{2}{c}{ Non-poor } \\
\cline { 2 - 5 } & $\mathrm{n}$ & $\%$ & $\mathrm{n}$ & $\%$ \\
\hline Yes & 51240 & $4.67 \%$ & 40108 & $1.81 \%$ \\
No & 1045519 & $95.33 \%$ & 2179793 & $98.19 \%$ \\
Total & 1096760 & $100.00 \%$ & 2219901 & $100.00 \%$ \\
\hline
\end{tabular}

Regarding the amount of poor and non-poor who have been enrolled in the 2015-2016 school year, it can be seen that in spite of the fact that the percentage of access to education is high for both instances, the amount of non-poor who have not been enrolled is $1.75 \%$ less than the poor's who did do it. Although this number may seem small, it is important to keep in mind that if we consider the proportion, which represents (due to the mount of poor and non-poor) enrolments for the poor is still low (Table 7).

Table 7. Enrolled in the 2015-2016 school year

\begin{tabular}{ccccc}
\hline & \multicolumn{2}{c}{ Poor } & \multicolumn{2}{c}{ Non-poor } \\
\cline { 2 - 5 } & $\mathrm{n}$ & $\%$ & $\mathrm{n}$ & $\%$ \\
\hline Yes & 1056726 & $96.35 \%$ & 2177682 & $98.10 \%$ \\
No & 40034 & $3.65 \%$ & 42219 & $1.90 \%$ \\
Total & 1096760 & $100.00 \%$ & 2219901 & $100.00 \%$ \\
\hline
\end{tabular}

The institutions that have more enrollments in both segments are the public schools; however, the non-poor opt, in an important percentage, to enrol in private schools. In 2015, 29004 poor enter a private school, which means they had to distribute costs based on enrolment and tuitions while 442046 non-poor were part of the mentioned process. It is evident that the non-poor have a bigger opportunity to enter private institutions (proportion of 15 to 1), or even fiscomisional schools, which receive monetary support from both the government and parents (proportion of 4 to 1) (Table 8). 
Table 8. The school where students were enrolled

\begin{tabular}{lcccc}
\hline & \multicolumn{2}{c}{ Poor } & \multicolumn{2}{c}{ Non-poor } \\
\cline { 2 - 5 } & $\mathrm{n}$ & $\%$ & $\mathrm{n}$ & $\%$ \\
\hline Public & 1001114 & $91.28 \%$ & 1623041 & $73.11 \%$ \\
Private & 29004 & $2.64 \%$ & 442046 & $19.91 \%$ \\
Municipal, fiscomisional & 26607 & $2.43 \%$ & 112596 & $5.07 \%$ \\
NA & 40034 & $3.65 \%$ & 42219 & $1.90 \%$ \\
Total & 1096760 & $100.00 \%$ & 2219901 & $100.00 \%$ \\
\hline
\end{tabular}

Although the presence of new technology in the educational process have been gaining more and more presence, Ecuador would not be considered a country with high indices of introduction of telecommunications (mobile devices). Regarding the population of analysis, it can be said that only 233462 children (7\%) have an active cell phone, out of them 36867 and the rest majority of poor (Table 9).

Table 9. Have an active cell phone

\begin{tabular}{ccccc}
\hline & \multicolumn{2}{c}{ Poor } & \multicolumn{2}{c}{ Non-poor } \\
\cline { 2 - 5 } & $\mathrm{n}$ & $\%$ & $\mathrm{n}$ & $\%$ \\
\hline Yes & 36867 & $3.36 \%$ & 196595 & $8.86 \%$ \\
No & 1056089 & $96.29 \%$ & 2006130 & $90.37 \%$ \\
NA & 3803 & $0.35 \%$ & 17176 & $0.77 \%$ \\
Total & 1096760 & $100.00 \%$ & 2219901 & $100.00 \%$ \\
\hline
\end{tabular}

If the phones were of standard or high range, which are advisable for educational interaction, only 103414 would be counted and of those, only 9881 would be possessed by poor children. In this last case, the proportion of ownership of smartphones is of 9 in hands of the non-poor for each of the considered poor (Table 10).

Table 10. The cell phone is smartphone

\begin{tabular}{ccccc}
\hline & \multicolumn{2}{c}{ Poor } & \multicolumn{2}{c}{ Non-poor } \\
\cline { 2 - 5 } & $\mathrm{n}$ & $\%$ & $\mathrm{n}$ & $\%$ \\
\hline Yes & 9881 & $0.90 \%$ & 93533 & $4.21 \%$ \\
No & 26986 & $2.46 \%$ & 103062 & $4.64 \%$ \\
NA & 1059892 & $96.64 \%$ & 2023306 & $91.14 \%$ \\
Total & 1096760 & $100.00 \%$ & 2219901 & $100.00 \%$ \\
\hline
\end{tabular}

Regarding the use of a computer, not necessarily ownership of a computer, in 2015, 1415028 children did not have access to one. However, regarding the access to the mentioned device, 1382303 used it compared to only 498351 poor, proportion which represents 2.77 to 1 . The amount of non-poor who used a computer is superior to the entirety of the existent poor at the mentioned ages in the country (Table 11).

Table 11. In the last 12 months you have used a computer

\begin{tabular}{ccccc}
\hline & \multicolumn{2}{c}{ Poor } & \multicolumn{2}{c}{ Non-poor } \\
\cline { 2 - 5 } & $\mathrm{n}$ & $\%$ & $\mathrm{n}$ & $\%$ \\
\hline Yes & 498351 & $45.44 \%$ & 1382303 & $62.27 \%$ \\
No & 594606 & $54.21 \%$ & 820422 & $36.96 \%$ \\
NA & 3803 & $0.35 \%$ & 17176 & $0.77 \%$ \\
Total & 1096760 & $100.00 \%$ & 2219901 & $100.00 \%$ \\
\hline
\end{tabular}


In 2015, 1539000 children in Ecuador did not use the internet, 651510 poor and 887490 non-poor (Table 12).

Table 12. In the last 12 months you have used a computer

\begin{tabular}{ccccc}
\hline & \multicolumn{2}{c}{ Poor } & \multicolumn{2}{c}{ Non-poor } \\
\cline { 2 - 5 } & $\mathrm{n}$ & $\%$ & $\mathrm{n}$ & $\%$ \\
\hline Yes & 441446 & $40.25 \%$ & 1315235 & $59.25 \%$ \\
No & 651510 & $59.40 \%$ & 887490 & $39.98 \%$ \\
NA & 3803 & $0.35 \%$ & 17176 & $0.77 \%$ \\
Total & 1096760 & $100.00 \%$ & 2219901 & $100.00 \%$ \\
\hline
\end{tabular}

Regarding the use, 1315235 of the non-poor segment mainly used a computer from home and then from centers of public access whereas 441446 poor mainly had access to the internet from the centers of public access and from their educational institutions. Only 71905 of them accessed the internet from their homes (Table 13).

Table 13. In the last 12 months where you used the internet more often

\begin{tabular}{ccccc}
\hline & \multicolumn{2}{c}{ Poor } & \multicolumn{2}{c}{ Non-poor } \\
\cline { 2 - 5 } & $\mathrm{n}$ & $\%$ & $\mathrm{n}$ & $\%$ \\
\hline Home & 71905 & $6.56 \%$ & 673491 & $30.34 \%$ \\
Work & 64 & $0.01 \%$ & 2301 & $0.10 \%$ \\
Educational Institution & 129354 & $11.79 \%$ & 198675 & $8.95 \%$ \\
Centers of Public Access & 217380 & $19.82 \%$ & 389629 & $17.55 \%$ \\
Someone else's home & 14789 & $1.35 \%$ & 41386 & $1.86 \%$ \\
Others & 7955 & $0.73 \%$ & 9753 & $0.44 \%$ \\
NA & 655313 & $59.75 \%$ & 904666 & $40.75 \%$ \\
Total & 1096760 & $100.00 \%$ & 2219901 & $100.00 \%$ \\
\hline
\end{tabular}

Despite the fact that a great population segment that accessed the internet do not specify the specific purpose of use, there is evidence that points out that the poor and non-poor mainly use the internet for educational and learning processes; communication in general. However, the non-poor compared to the poor do use the internet for leisure and recreational activities (obtain movies, read, among others) (Table 14).

Table 14. In the last 12 months what you used the internet for

\begin{tabular}{lcccc}
\hline & \multicolumn{2}{c}{ Poor } & \multicolumn{2}{c}{ Non-poor } \\
\cline { 2 - 5 } & $\mathrm{n}$ & $\%$ & $\mathrm{n}$ & $\%$ \\
\hline Obtain information & 93933 & $8.56 \%$ & 313175 & $14.11 \%$ \\
Communication in general & 73672 & $6.72 \%$ & 212500 & $9.57 \%$ \\
Buy/order products or services & 160 & $0.01 \%$ & 1358 & $0.06 \%$ \\
Electronic Banking and financial services & 559 & $0.05 \%$ & 2973 & $0.13 \%$ \\
Education and learning & 265640 & $24.22 \%$ & 725932 & $32.70 \%$ \\
Transactions with organizations & 176 & $0.02 \%$ & 99 & $0.00 \%$ \\
Entertainment Activities & 6490 & $0.59 \%$ & 49099 & $2.21 \%$ \\
Obtain movies, music or software & 0 & $0.00 \%$ & 7603 & $0.34 \%$ \\
Read/download electronic books & 0 & $0.00 \%$ & 813 & $0.04 \%$ \\
\hline
\end{tabular}




\begin{tabular}{lcccc}
\hline Work reasons & 250 & $0.02 \%$ & 270 & $0.01 \%$ \\
Others & 566 & $0.05 \%$ & 1413 & $0.06 \%$ \\
NA & 655313 & $59.75 \%$ & 904666 & $40.75 \%$ \\
Total & 1096760 & $100.00 \%$ & 2219901 & $100.00 \%$ \\
\hline
\end{tabular}

Regarding the frequency, excluding a big number of persons who do not indicate the frequency, the poor and non-poor access the internet, daily access prevails (at least once a day) in the non-poor segment while in the poor the prevailing frequency is of at least once a week (Table 15).

Table 15. How often you used the internet in the last 12 months

\begin{tabular}{lcccc}
\hline & \multicolumn{2}{c}{ Poor } & \multicolumn{2}{c}{ Non-poor } \\
\cline { 2 - 5 } & $\mathrm{n}$ & $\%$ & $\mathrm{n}$ & $\%$ \\
\hline At least once a day & 183474 & $16.73 \%$ & 813059 & $36.63 \%$ \\
At least once a week & 244156 & $22.26 \%$ & 466844 & $21.03 \%$ \\
At least once a month & 12261 & $1.12 \%$ & 32648 & $1.47 \%$ \\
At least once a year & 1556 & $0.14 \%$ & 2000 & $0.09 \%$ \\
Don't know & 0 & $0.00 \%$ & 684 & $0.03 \%$ \\
NA & 655313 & $59.75 \%$ & 904666 & $40.75 \%$ \\
Total & 1096760 & $100.00 \%$ & 2219901 & $100.00 \%$ \\
\hline
\end{tabular}

\section{Conclusion}

The objective of the study was to examine the educational and social profile of young people aged 5-14 of Ecuador by means of a statistical analysis of this sector of the Ecuadorian population, based on data from the National Survey of Employment, Unemployment and Underemployment from 2015. A descriptive statistical analysis showed the frequencies and percentages of the variables used in the investigation (Stefos et al., 2016; Olivier, 2008). We used contingency tables in order to explore the relationship between the variables under investigation and the poverty in this age group (5-14). After carrying out this study, it is relevant to highlight the following aspects:

- In Ecuador, children considered non-poor have more opportunity to enter private schools (proportion of 15 to 1 ), or even the fiscomisional schools (proportion of 4 to 1 ).

- Likewise, it can be seen that, in the country, there is not a high rate of technological penetration (mobile phones) regarding children of 5 to 14 years old since out of 3316661 children (both poor and non-poor), only 233462 children (7\%) have an active cell phone. Of this group, the proportion of ownership of smartphones is of 9 in hands of the non-poor for each considered poor (Stefos, 2015; Papapostolou et al., 2013).

- Regarding the access to a computer, in Ecuador 1382303 non-poor used it compared to 498351 poor who did not, proportion that represents 2.77 to 1 . The amount of non-poor that used a computer is superior to the entirety of the existent poor children at the mentioned ages in the country (Bonilla Marchán et al., 2017; Stefos \& Efstathiou, 2013).

\section{Acknowledgments}

We would like to express our deepest gratitude to UNESCO Chair on Support Technologies for Educational Inclusion, Universidad Politécnica Salesiana and Universidad Nacional de Educación UNAE that supported our investigation. 


\section{References}

Asamblea Nacional del Ecuador. (2011). Ley Orgánica de Educación Intercultural_LOEI. Quito.

Bonilla Marchán, A., Ramiro Delgado, R., \& Stefos, E. (2017). The Social Characteristics of Postgraduate Students in Ecuador: A Multidimensional Statistical Analysis. Review of European Studies, 9(2), 35-44. https://doi.org/10.5539/res.v9n2p35

Castellano, J. M., Stefos, E., \& Williams Goodrich, L. G. (2017). The Educational and Social Profile of the Indigenous People of Ecuador: A Multidimensional Analysis. Review of European Studies, 9(1), 137-147. https://doi.org/10.5539/res.v9n1p137

Instituto Nacional de Estadística y Censos-INEC. (2006). Encuesta Nacional de Empleo, Desempleo y Subempleo-ENEMDU, 2006. Quito, Ecuador.

Instituto Nacional de Estadística y Censos-INEC. (2015). Encuesta Nacional de Empleo, Desempleo y Subempleo-ENEMDU, 2015. Quito, Ecuador.

Kampouropoulou, M., Fokiali, P., Efstathiou, I., Koutris, T., \& Stefos, E. (2015). Students' Views on the Use of a Virtual Educational Museum. Review of European Studies, 7(11), 1-6. https://doi.org/10.5539/res.v7n11p1

OECD. (2015). Education at a Glance 2015: OECD Indicators. OECD Publishing. https://doi.org/10.1787/eag-2015-en

Olivier, M. (2008). The analysis of quantitative data (I. Athanasiadis, Trans., pp. 86-88). Athens: Topos.

Papapostolou, I., \& Stefos, E. (2013). Qualitative analysis on pedagogical research. Methodological approaches. In I. Papapostolou (Ed.), Educational activities. Teaching Interventions in Secondary Education (pp. 244-251). Rhodes: Evdimos Editions.

Papapostolou, I., Papapostoulou, K., \& Stefos, E. (2013). Educational Research. In From Qualitative to Quantitative analysis (p. 178). Rhodes: Evdimos Editions.

Sarmiento Sarmiento, N. M., Paredes Proaño, A. M., \& Stefos, E. (2016). Deaths by Suicide in Ecuador: A Quantitative Data Analysis. Review of European Studies, 8(1), 145-156. https://doi.org/10.5539/res.v8n1p145

Secretaria Nacional de Planificación y Desarrollo-SENPLADES. (2013). Plan Nacional para el Buen Vivir 2013-2017. Quito.

Stefos, E. (2015). Causes of Death of Indigenous Ecuadorians. International Journal of Clinical Medicine Research, 2(6), 65-70.

Stefos, E., \& Efstathiou, I. (2013). Quantitative analysis of the data of the School of Trianta during the period of 1906-1916. In I. Papapostolou (Ed.), Educational activities. Teaching Interventions in Secondary Education (pp. 29-57). Rhodes: Evdimos Editions.

Stefos, E., \& Koulianidi, G. (2016). Nutrition Data Analysis Using R: Applications in Higher Education. Health Sciences Research, 3(1), 10-16.

Stefos, E., \& Papapostolou, I. (2013). Research Methodology. In Processes and suggestions (p. 406). Rhodes: Evdimos Editions.

Stefos, E., Benalcázar Jiménez, M. E., Coral Carvajal, M. M., Córdova Vargas, P. A., Landázuri Muñoz, M. B., Lombeida Saltos, E. S., ... Yajamín Villamarín, R. X. (2016). A Data Analysis of Social and Educational Characteristics of Ecuadorians Aged 25-64. AASCIT Communications, 3(3), 184-189.

Stefos, E., Athanasiadis, I., Gialamas, B., \& Tsolakidis, C. (2011). The Use of New Technologies and the Project Method in Teaching Statistics: A Case Study in Higher Education. HMS i JME, 3, 84-100.

Valdivieso, G., Stefos, E., \& Lalama R. (2017). The Ecuadorian Amazon: A Data Analysis of Social and Educational Characteristics of the Population. Review of European Studies, 9(1), 120-129. https://doi.org/10.5539/res.v9n1p120

Williams Goodrich, L. G., Castellano, J. M., \& Stefos, E. (2017). An Analysis of the Social Profile of 15 to 17 Year Old Students in Ecuador Regarding Secondary School Attendance and Truancy. Review of European Studies, 9(2), 91-105. https://doi.org/10.5539/res.v9n2p91 


\section{Copyrights}

Copyright for this article is retained by the author(s), with first publication rights granted to the journal.

This is an open-access article distributed under the terms and conditions of the Creative Commons Attribution license (http://creativecommons.org/licenses/by/4.0/). 